\title{
Orientalsk Afdelings mongolske samling
}

af forskningsbibliotekar, mag.art. Frede Møller-Kristensen

En af verdens storste og mest betydningsfulde samlinger af mongolske håndskrifter og bloktryk befinder sig $i$ dag $i$ Det kongelige Bibliotek. Samlingen skyldes isar filologen, dr.phil. Kaare Grønbech, der indsamlede den på den 2. danske centralasiatiske ekspedition 1938-39. I modsatning til de fleste andre samlinger $i$ den vestlige verden omfatter den ikke kun lamaistiske varker, men nasten alle grene af mongolsk litteratur.

Når talen falder på mongolerne, tænker de fleste vesterlændinge først og fremmest på de voldsomme hære af bevæbnede nomaderyttere, der i 1200tallet erobrede det meste af Asien og store dele af Europa.

På deres vej hærgede og plyndrede de og lagde store byer $\emptyset$ de.

Manden bag de første erobringstog, der udgik fra Mongoliets stepper, var en stammehøvding ved navn Temudjin (1167? - 1227).

Hans stamme hørte hjemme ved floden Onon sydøst for Bajkal-søen. Han besejrede sine nabostammer og fik til sidst samlet alle mongolfolkets stammer under sig. I 1206 ophøjede de undergivne nomadestammer ham til hersker. Han tog navnet Djingis og titlen Khan. I løbet af kun 30 år (1211 1241) beherskede Djingis Khan og hans efterfølgere et imperium, der strakte sig fra Det gule Hav i øst til langt ind i Europa i vest.

I flere formationer drev de mongolske ryttere 1240-41 kiler ind i Europa fra sydøst. Den ene fløj, der slog en tysk-polsk ridderhær ved Liegnitz i Schlesien 1241, var allerede på tysk jord, den anden havde samtidig besejret ungarerne, da det blev besluttet at samle hærenhederne i Ungarn. Samme år trak de sig pludselig tilbage til egnene omkring Volga.

Indre statsanliggender var årsag til den pludselige tilbagetrækning. Ögödei, Djingis Khans søn og efterfølger, var afgået ved døden. Det var derfor magtpåliggende for de mongolske høvdinge at komme tilbage til Mongoliet så hurtigt som muligt for at deltage i valget om at blive den nye khan. 
Mongolerne vendte aldrig tilbage til Europa - Mellemøstens og Kinas rigdomme var mere tillokkende.

Omkring 1250 vendte mongolerne sig mod Sydkina, hvor Sung-kejserne herskede. Efter næsten 30 års kamp var Sung-dynastiets magt brudt i 1279.

Et nyt dynasti (Yüan) blev grundlagt af Kublai Khan (1260-94), Djingis Khans sønnesøn.

Efter Yüan-dynastiets fald i 1368 trak mongolerne i Kina sig helt tilbage til deres gamle stammeland i Nord- og Nordøstmongoliet - og lidt efter lidt gik det vældige rige i opløsning.

De to største koncentrationer af mongoler lever i dag dels i Den mongolske Folkerepublik, der har et indbyggertal på omkring 2 millioner, og dels i Indre Mongoli, der er et autonomt område i Den kinesiske Folkerepublik.

I Indre Mongoli tæller den mongolske befolkning 3,3 millioner svarende til 13,5 procent af områdets samlede befolkningstal. Der bor omkring 400.000 mongoler i Sovjetunionen, og et ukendt antal mongoler lever spredt i forskellige kinesiske provinser.

Det mongolske sprog hører til den altaiske sprogfamilie, der blandt andet også tæller de tyrkiske sproggrupper.

Klassisk mongolsk er det skriftsprog, som oversætterne af den tibetanske lamaistiske kanon (Kanjur) benyttede i begyndelsen af 1600-tallet. Et hundrede år senere fik det mongolske skriftsprog sin endelige form, idet der i Peking blev xylograferet en revideret udgave af den mongolske Kanjur.

Dette sprog blev normen for det litterære sprog helt op til vor tid.

Moderne mongolsk opdeles i en række dialekter. Khalkha er den dialekt, der tales i Den mongolske Folkerepublik. Ordos og Tsakhar er de mest kendte dialekter i Indre Mongoli.

Det var dette folk - det mongolske og dets kultur, der begejstrede den danske opdagelsesrejsende og etnograf Henning Haslund-Christensen (1896-1948) allerede $\mathrm{i}$ en tidlig alder.

Den danske læge Carl Krebs (1889-1971), som Haslund-Christensen kendte fra sin tid ved militæret, oprettede i 1923 en forsøgsgård og en station for pelshandel på Bulguntal-sletten sydvest for Bajkal-søen.

Haslund-Christensen og nogle andre unge var med fra starten i 1923. De politiske forhold besværliggjorde imidlertid deres arbejde i den grad, at de forlod farmen i 1926. Kun Carl Krebs blev tilbage.

Under opholdet på forsøgsgården lærte Haslund-Christensen sig mongolsk. I sin bog Jabonah fra 1932 skildrer han blandt andet dagligdagen på farmen, 
rejser i forbindelse med opk $\varnothing \mathrm{b}$ af pelsværk og forholdet til den mongolske befolkning.

I Peking kom Haslund-Christensen i kontakt med den store svenske opdagelsesrejsende Sven Hedin. I 1927-1930 virkede han som karavanefører for 300 kameler og 70 mand. På denne ekspedition studerede Haslund-Christensen især mongolsk folkemusik, som han optog på voksvalser. Han blev således en foregangsmand inden for musiketnografien.

Sine oplevelser på Hedin-ekspeditionen har han levende beskrevet i rejseskildringen Zajagan fra 1935.

Gennem foredrag og bøger blev Haslund-Christensens navn kendt vidt og bredt. Hans indgående kendskab til mongolernes sæder og skikke gjorde det naturligt, at han blev udpeget til organisator og leder af kommende danske ekspeditioner til Centralasien.

Den første danske centralasiatiske ekspedition (1936-1937), der gik til Østmongoliet, blev bekostet af Nationalmuseet. Haslund-Christensens indsamlinger af etnografisk materiale, blandt andet dragter og smykker, vakte ved hans hjemkomst stor opsigt.

Det kongelige danske geografiske selskab forsynede Haslund-Christensen med midler til en ny rejse til Mongoliet (den anden danske centralasiatiske ekspedition 1938-1939). Her deltog endvidere arkæologen Werner Jacobsen og filologen Kaare Grønbech - sidstnævnte med det formål at gøre linguistiske studier samt indsamle skriftligt materiale.

Under og lige efter anden verdenskrig planlagde Haslund-Christensen flere ekspeditioner. Mindre grupper af forskere skulle rejse til forskellige områder i Asien. Disse ekspeditioner fik fællesbetegnelsen: den tredie danske centralasiatiske ekspediton.

Den første gruppe med Haslund-Christensen som leder udgik fra København i oktober 1947 med Afghanistan som mål. Ekspeditionens forskellige grupper var i arbejde indtil 1954 - men kun med Haslund-Christensen som leder et års tid, idet døden indhentede ham i Kabul september måned 1948.

Af de nævnte ekspeditioner er det den anden (1938-1939), der har st $\varnothing r s t$ betydning i denne sammenhæng. På denne ekspedition blev der for første gang i Vesten taget hensyn til sproglige studier i det Indre Mongoli. Tidligere vesteuropæiske ekspeditioner til disse egne af Mongoliet havde hovedsagelig beskæftiget sig med naturvidenskabelige emner.

Som nævnt blev det Kaare Grønbech (1901-1957), der skulle varetage ekspeditonens filologiske opgaver.

Disputatsen Der türkische Sprachbau I (1936) havde skaffet Kaare Grønbech megen anerkendelse ude i verden. Medens han fortsatte arbejdet med den tyrkiske sprogbygning, var han tillige stærkt optaget af studiet af mon- 


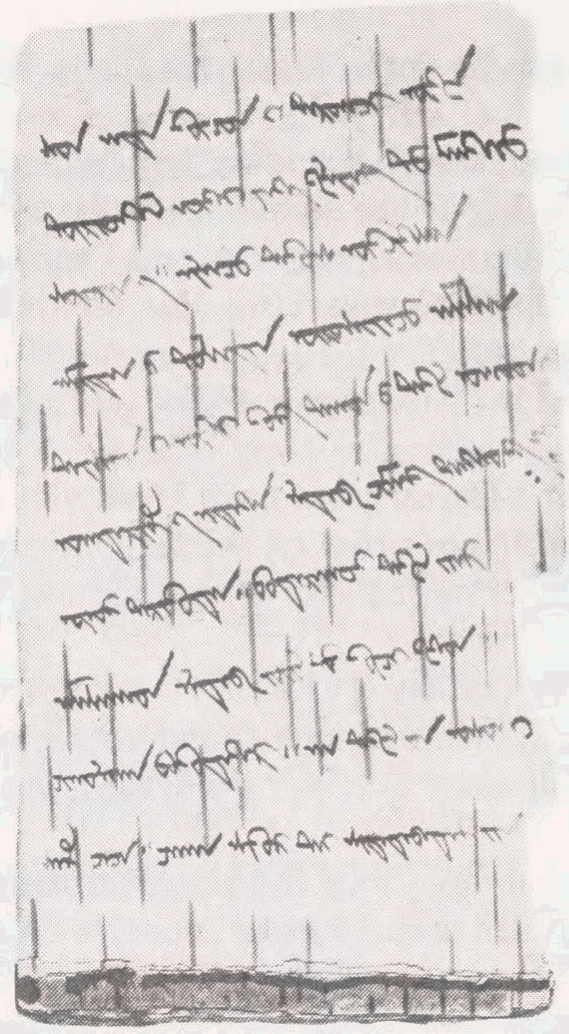

Buddhistisk dharani (magisk formel). Det første mongolske håndskrift i bibliotekets eje. Skrevet på birkebark. (MONG 158).

golsk. Han var derfor selvskreven som deltager i den anden danske centralasiatiske ekspedition.

Det var Kaare Grønbechs opgave at gøre dialektstudier i disse i sproglig henseende ringe udforskede områder samt indsamle mongolske håndskrifter og bloktryk for at tilvejebringe materiale til studiet af mongolsk sprog og historie. Det var i sidste $\varnothing$ jeblik, indså man. De mongolske stammer ville uvægerligt miste deres sproglige og kulturelle særpræg ved et uundgåeligt møde med den "moderne civilisation".

Ekspeditionen fik hovedkvarter i det nordlige Tsakhar. Herfra red Kaare Grønbech ofte ud til fjernere egne, ledsaget af en stedkendt mongol, for at søge håndskrifter og bloktryk.

Det rygtedes hurtigt blandt mongolerne, at ekspeditionen var interesseret $\mathrm{i}$ at købe skriftligt materiale - og at den betalte godt.

Når han indfandt sig i et telt for at handle, kom mongolerne strømmende til fra alle kanter for at sælge deres håndskrifter og tryk.

De kom nu også til ekspeditionens lejr for at sælge. På denne måde erhvervede Kaare Grønbech nogle betydningsfulde håndskrifter af mongolske krøniker, som på daværende tidspunkt var ukendte for vestlige forskere. 
Vigtige håndskrifter, som han ikke kunne erhverve, affotograferede han på stedet.

Blandt Tsakhar-mongolerne lod Kaare Grønbech en række mundtligt overleverede fortællinger nedskrive.

Hjemtransporten foregik ikke uden vanskeligheder. Det var urolige tider. Spionagen florerede. Det var derfor vanskeligt at få det skrevne materiale gennem tolden. Det lykkedes omsider efter mange nervepirrende forhandlinger at bringe den værdifulde last ombord på et ØK-skib med kurs mod Danmark.

De mest betydningsfulde håndskrifter - håndskrifter af mongolsk digtning og krønikeskrivning hidtil ukendte for den lærde verden i Vesten - var for en sikkerheds skyld indrullet i beklædningsgenstande i de personlige kufferter.

Det indsamlede materiale var egentlig tænkt som kernen i et centralasiatisk institut, der skulle oprettes i København. Planen om et sådant institut blev imidlertid skrinlagt med udbruddet af den anden verdenskrig.

Samlingen blev af sikkerhedsgrunde gemt væk - bortset fra nogle få typiske håndskrifter og bloktryk, der blev deponeret på Nationalmuseet til udstillingsbrug. Her befinder de sig stadig.

I 1949 blev det med Kaare Grønbechs billigelse besluttet, at den store mongolske samling skulle indgå i Det kongelige Bibliotek.

Orientalsk Afdelings mongolske samling omfatter i dag over 500 mongolske håndskrifter og bloktryk. I samlingen indgår desuden en række film, optaget af Kaare Grønbech under ekspeditionen, af vigtige håndskrifter, der ikke tidligere var kendt i vesten. Det lykkedes ikke at erhverve disse håndskrifter. Deres videre skæbne kendes ikke, men takket være Grønbechs indsats er deres indhold i dag tilgængeligt for hele den internationale forskning.

Orientalsk Afdelings mongolske samling er en af de største og mest betydningsfulde i verden, når vi ser bort fra Mongoliet og Sovjetunionen. Til sammenligning skal eksempelvis nævnes bestanden af mongolske værker et par andre steder i verden: Belgien (46 håndskrifter og bloktryk), Bern (45), Cambridge (35), Dublin (52), Kyoto (49), London (2 samlinger: $34+105$ ), Paris (2 samlinger: $40+165)$, Stockholm (126), Tokyo (230), Vesttyskland (12 samlinger på tilsammen 672) og Washington (81).

De fleste af de mongolske værker, der findes i de øvrige samlinger (uden for Mongoliet og Sovjetunionen), er værker af lamaistisk indhold. I den mongolske samling i Orientalsk Afdeling er derimod næsten alle grene af den mangesidige mongolske litteratur repræsenteret.

En meget omfattende mongolsk samling findes i International Academy of Indian Culture i New Delhi, men det drejer sig udelukkende om buddhistiske 
værker på mongolsk. Hvad der findes af mongolsk materiale i Peking, vides ikke.

Fra gammel tid har der eksisteret en lille mongolsk samling (Gamle Samling) på Det kongelige Bibliotek. Den bestod af syv værker. Det første mongolske håndskrift $\mathrm{i}$ bibliotekets eje er en stor sjældenhed. Det er en buddhistisk dharani (magisk formel), skrevet på birkebark. Det lille håndskrift på 11 blade er fra begyndelsen af 1600-tallet. Kun ganske få håndskrifter på birkebark af en sådan alder er bevaret. Codices Orientales Bibliotheca Regice Hafniensis III fra 1857 beskriver det i al korthed således: Codex Mongolicus. XI folia corticis Betulini amuletum, quod Tarni dicitur, exhibent.

Gamle Samling fik en tilvækst på 20 mongolske værker i årene 1922-24. Senere blev den ældre del af bibliotekets mongolske samling suppleret yderligere med lamaistisk litteratur (især kanoniske hovedværker), indkøbt af Haslund-Christensen under hans ekspedition til Mongoliet 1936-1937.

På den anden danske centralasiatiske ekspedition kunne man derfor se bort fra de mest benyttede buddhistiske værker, da de allerede fandtes i København. Kaare Grønbech kunne koncentrere sig om andre sider af den buddhistiske litteratur, samt hele den verdslige.

Lamaistisk litteratur omfatter ikke alene de værker, der omhandler buddhismens tanke-indhold. Den omfatter også de større eller mindre tekster, der anvendes i forbindelse med dagligdagens gøremål. Dette kan være medicinske tekster eller tekster, der beskriver forskellige rituelle handlinger. Det var tekster af denne art, der havde Kaare Grønbechs interesse.

Der er tradition for at dyrke medicinske studier i klostrene overalt i den buddhistiske verden. Er klostret afsides beliggende, er det ligefrem en nødvendighed at kunne helbrede sig selv og sine medbrødre. Endvidere virker munkene ofte som læger for den jævne befolkning. Foruden at hjælpe udøver de en from og fortjentsfuld gerning.

Adskillige tekster, der omhandler medicinske emner, findes i den mongolske samling, blandt andet et medicinsk hovedværk (MONG 444), der er oversat fra tibetansk. Det beskriver de enkelte sygdomme, diagnosen og sygdommens årsager og helbredelse. Den sidste del af værket indeholder en fysiologi.

I samlingen indgår også en lang række lamaistiske tekster, der anvendes rituelt ved bestemte lejligheder, for eksempel i forbindelse med dødsfald.

Efter døden kastes liget ud på steppen. MONG 560 giver nøje regler for hvilke dage, der er gunstige og hvilke, der er ugunstige for fjernelse af liget fra hjemmet.

MONG 172 er en tekst med anvisninger på et røgelsesoffer til Chaghan ebügen (den Hvide Olding). Der er tale om et renselsesoffer. Selve ofringen 


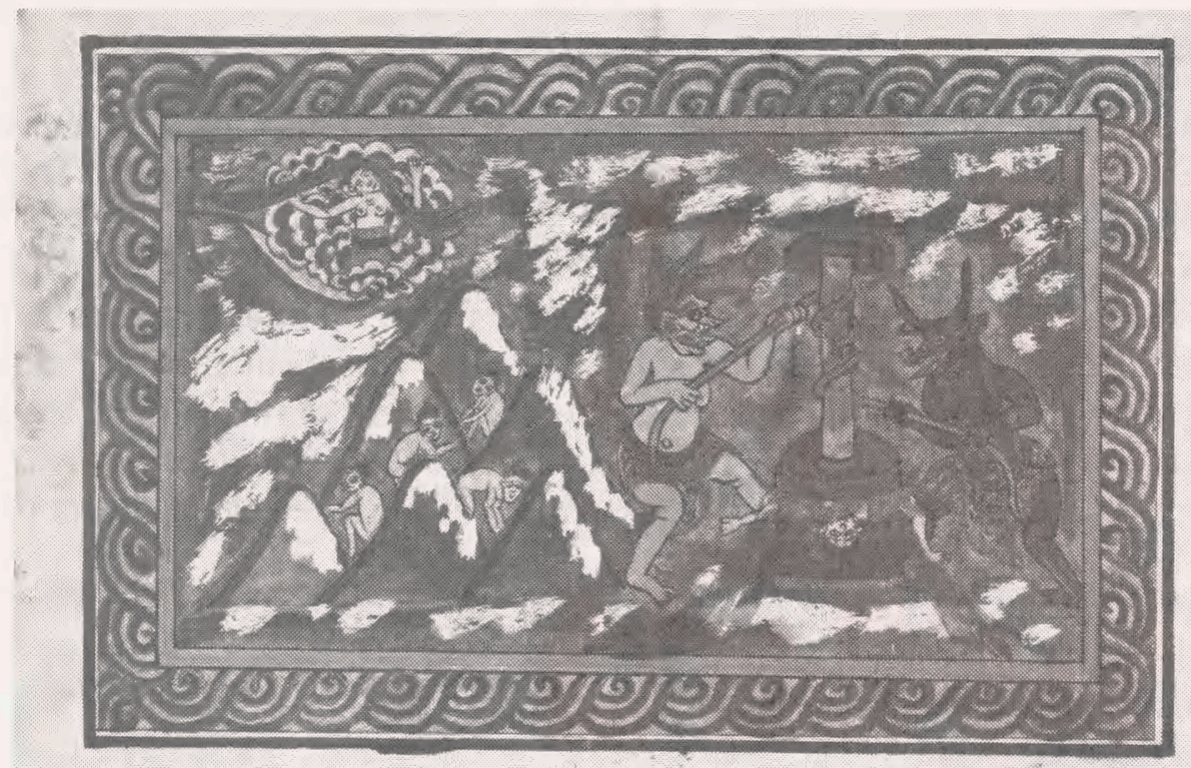

Fra legenden om den fromme Molon toyin, der drager til underverdenen for at frelse sin moder fra de buddhistiske helveder. Han passerer pås sin vandring de 8 varme og de 8 kolde helveder, hvor de fordømte må lide deres straf. Illumineret håndskrift. (MONG 417).

består af røgelse, lamper og føde. Der stænkes med vin, og der afbrændes enebærkviste. Chaghan ebügen anråbes blandt andet for at opnå velsignelse af bopladsen, undertrykkelse af hindringer og dæmoner, hindring af kvægsygdomme, ødelæggelse af fjender, samt for at opnå sikker rejse. Chaghan ebügen er en oprindelig mongolsk skikkelse, der har sneget sig ind i den lamaistiske forestillingsverden.

I samlingen er endvidere indgået to små biblioteker, der har tilhørt omrejsende lamaer. Det ene bibliotek omfatter 17 tekster: to dogmatiske, tre med lamaistiske bønner, en medicinsk tekst og 11 ritualtekster.

Til den verdslige litteratur hører en for mongoleme vigtig gruppe tekster. Den består af håndbøger i astronomi og astrologi, kalendere og tekster vedrørende divination. Man kan ikke udføre ret mange daglige gøremål uden at rådføre sig med en af de nævnte håndbøger.

Det gælder om at finde det mest gunstige tidspunkt til udførelsen af handlingen. Der er dage, der er mere egnede end andre til for eksempel at slagte kvæg eller klippe får. Der er dage, hvor man ikke må holde bryllup eller mærke sit kvæg.

Man kan spå efter planeternes stilling. Man kan også spå ved hjælp af terninger eller mønter. MONG 325 er en håndbog i spådomskunst, hvor man anvender ni mønter. Den ene af mønterne forsynes med et mærke. Alle ni mønter holdes mellem håndfladerne, medens bønnen fremsiges. Mønterne 
anbringes på venstre håndflade, $\mathrm{og}$ med højre hånd blandes de. Man lader nu mønterne glide ud af håndfladen en for en. I det øjeblik den mærkede mønt falder, er kapitlet, der skal rådspørges i håndbogen, samtidig angivet (i rækken en til ni).

En anden form for divination udføres ved hjælp af skulderbladet fra et nyslagtet får. Skulderbladet stikkes ind i ilden. Under afkølingen opstår der revner i skulderbladet. Ud fra disse revner aflæser man, hvorledes man skal forholde sig $\mathrm{i}$ en given situation. I håndbøger findes der diagrammer med forskellige placeringer af revnerne på skulderbladet og anvisninger på, hvorledes de skal tydes. MONG 125 og MONG 260 i samlingen er eksempler på håndbøger i denne form for divination.

Den fortællende litteratur er rigt repræsenteret i den mongolske samling. Denne litteraturtype stammer fra Indien, Kina og Tibet. Den kom til Mongoliet sammen med lamaismen.

I et tibetansk folkeepos berettes sagnene om Geserkhan, den store helt, der udøver vældige bedrifter blandt mennesker, guder og dæmoner. Ekspeditionen erhvervede et bloktryk og to håndskrifter af den mongolske version af dette epos. Det ene håndskrift indeholder en hidtil ukendt sang.

To meget skattede eventyrsamlinger i Mongoliet er Siditü kegür (Det forheksede lig) og Arji-borji. Det er de mongolske versioner af to kendte indiske eventyrsamlinger: Vetalapancavimsatika og Simhasanadvatrimsatika, der er affattet på sanskrit.

Til den fortællende litteratur hører også legenden om den fromme Molon toyin (toyin betyder munk), der drager til underverdenen for at frelse sin moder fra de buddhistiske helveders kvaler.

Af tekstens lange titel fremgår det, at det drejer sig om en fortælling om den hellige bodhisattva (den kommende Buddha) Molon toyin, der lader sin moder få del i sine gode gerninger. Molon toyin er søn af en mongolsk fyrste. Efter faderens død beslutter Molon toyin at drage ud i verden for at drive handel. Inden afrejsen formaner han sin moder til at gøre gode gerninger. Så snart Molon toyin er rejst, begynder hans moder at bortødsle sin formue. Hun fylder sig med mad, og hun drikker alkohol. Hun synder og driver de buddhistmunke, der kommer for at forrette ofringer, på porten. Hun piner og plager dyrene, inden hun dræber dem. Hun tilbeder de gamle mongolske guder i stedet for at ære Buddha.

Da Molon toyin vender tilbage, fortæller naboerne ham om moderens syndige adfærd. Moderen benægter dette. Hun aflægger den ed, at hun vil blive alvorligt syg og d $\varnothing$, hvis hun ikke taler sandt. Hun dør syv dage senere.

Efter moderens død forsager han verden for at blive munk. Han bliver en 
af Buddhas nærmeste disciple. Det er Molon toyins mål af frelse sin moder fra helvedes kvaler. I kraft af de overnaturlige evner, som Buddha har udstyret ham med, begiver han sig på vandring gennem de otte varme og de otte kolde helveder. De grusomme og sadistiske torturscener, han møder på sin vej, er levende beskrevet i fortællingen. Når han støder på et sådant optrin, spørger han altid en af vogterne, hvad de stakkels mennesker har bedrevet, medens de levede på jorden, siden de udsættes for en sådan medfart. Han så for eksempel nogle, der var hængt op i træerne ved håret, og tunge sten var bundet til deres fødder. Derudover blev de tortureret med svøber og forke. Han spurgte en af vogterne, hvilke synder disse væsener havde begået. Vogteren svarede, at de måtte lide, fordi de ikke havde æret deres svigerforældre, deres fader og moder og buddhistmunkene - de havde derimod fornærmet dem.

Molon toyin finder endelige sin moder, men han kan ikke frelse hende ved egen hjælp. Buddha må træde til. Efter nogle uheldige genfødsler bliver hun endelig genfødt som en from og velgørende kvinde.

Fortællingen om Molon toyin har sit forbillede i den gamle buddhistiske Maudgalyayana-legende. Maudgalyayana var Buddhas yndlingsdiscipel.

I den mongolske samling findes tre versioner af fortællingen om Molon toyin. To af dem er med illustrationer. MONG 417, der er et illumineret håndskrift, er utvivlsomt et af de største klenodier i samlingen. Meget få biblioteker i verden er $\mathrm{i}$ besiddelse af illuminerede mongolske håndskrifter.

Illustrationerne i MONG 418 er farvelagte litografier.

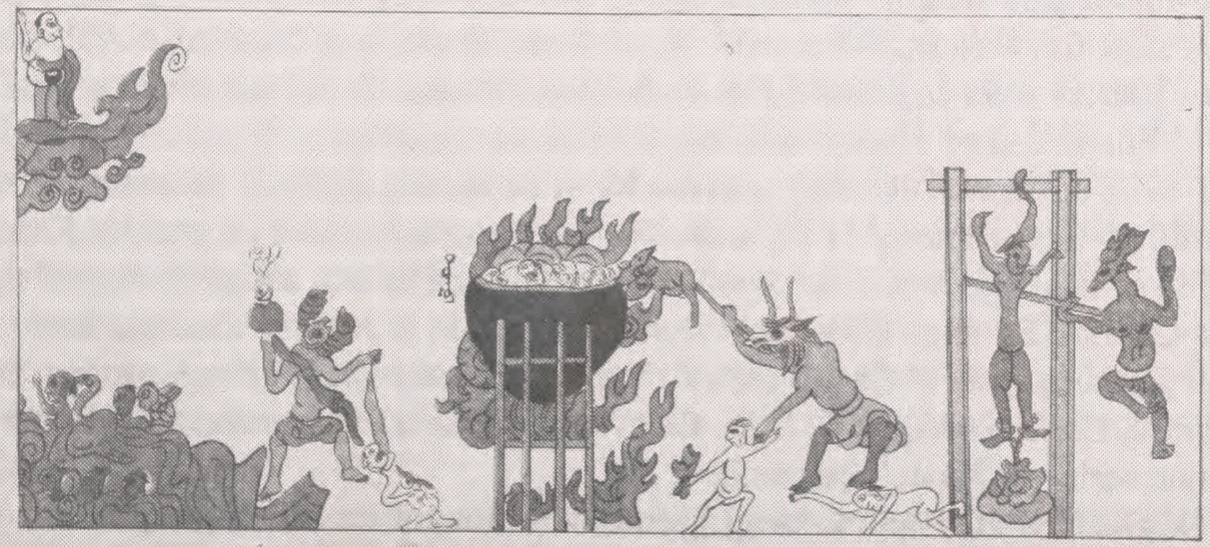

Tortur-scene fra et af de varme buddhistiske helveder, som den fromme Molon toyin passerer på sin vandring gennem underverdenen. Farvelagt xylografi. (MONG 418). 


\section{Historisk litteratur og kilder}

Skal nogen tekst-gruppe i den mongolske samling i særlig grad fremhæves, må det være den gruppe, der udgøres af den historiske litteratur.

Kaare Grønbech indsamlede på den anden danske centralasiatiske ekspedition over en halv snes krønike-håndskrifter og affotograferede talrige, som han ikke kunne erhverve. Det er den første større samling mongolske kildeskrifter, der er bragt til Vesteuropa. Den har intet sidestykke i nogen anden samling uden for Mongoliet og Sovjetunionen. Der findes tekster i samlingen, der indtil deres opdagelse af Kaare Grønbech var ganske ukendte. Inden ekspeditionen havde vestens lærde kun adgang til 2 - 3 mongolske krøniker. Man vidste dog, at der fandtes flere i de russiske biblioteker. Med Grønbechs indsamling og affotografering blev det endelig muligt for forskere i Vesteuropa at få et alsidigt indblik i den mongolske krønike-skrivning.

Hovedparten af det, der inden anden verdenskrig var skrevet i Europa om mongolernes historie, var baseret på persiske og kinesiske kilder. Mongolernes egne beretninger om deres krigeriske bedrifter og beretninger om livet hjemme på Centralasiens stepper var der ikke taget hensyn til. Hertil kommer, at mongolernes egne krøniker ofte er vore eneste kilder til belysning af århundrederne efter Yüan-dynastiets fald og til belysning af uroen blandt stammerne i det nordlige Mongoli i 1600- og 1700-tallet.

Kaare Grønbech indså klart, at her var en stor mangel i vort kildemateriale til mongolernes historie. Han var også klar over, at det skulle indsamles, inden det ville være for sent.

Dele af den mongolske samling $\mathrm{i}$ København har i adskillige årtier været kendt i det meste af den lærde verden - ikke mindst på grund af omtale af den i professor Walther Heissigs talrige publikationer.

Mange forskere fra hele verden har i årenes løb besøgt Orientalsk Afdeling for i kortere eller længere tid at studere de mongolske håndskrifter og bloktryk. Endvidere er et stort antal fotobestillinger indløbet.

I 1971 udkom en udførlig beskrivelse af de enkelte numre i den mongolske samling: Catalogue of Mongol Books, Manuscripts and Xylographs. Katalogen er udarbejdet af professor Walther Heissig (Bonn), assisteret af professor Charles Bawden (London). Den udkom som bind 3 i bibliotekets stort anlagte katalogserie Catalogue of Oriental Manuscripts, Xylographs etc. in Danish Collections (COMDC). En af initiativtagerne til grundlæggelsen af denne serie var Kaare Grønbech.

Udgivelsen af denne katalog gjorde den mongolske samling endnu mere kendt. Det bevirkede, at Orientalsk Afdeling blev et valfartssted for mongolister, tibetologer og buddhologer ikke blot fra den vestlige verden, men også i høj grad fra lande i Asien. 
Inden for de seneste år har Orientalsk Afdeling endog haft besøg af forskere fra Indre Mongoli - landet hvorfra nogle af samlingens betydeligste håndskrifter stammer. I maj måned 1988 gennemgik en professor og en bibliotekar fra Huhhot i Indre Mongoli hele den mongolske samling. I september 1989 bes $\varnothing$ gte en forsker, ligeledes fra Huhhot, Orientalsk Afdeling i 3 dage.

Benyttelsen af den mongolske samling har givet sig synlige udslag i form af udgaver og oversættelser af hele tekster. I talrige værker og afhandlinger om mongolsk sprog og kultur ses ofte citater af større eller mindre tekstafsnit eller henvisninger til de benyttede håndskrifter og bloktryk. Nogle eksempler vil vise, at de fleste tekstkategorier i samlingen benyttes i en eller anden sammenhæng.

Altan Gerel ('guldglans-sutraen' - MONG 557) hører til Gamle Samling. Den var udstillet på orientalistkongressen, der blev afholdt i København 1908. Teksten er udgivet af Erich Haenisch (Leipzig 1929). Guldglans-sutraen er et centralt kanonisk værk i mahayana-buddhismen. Mahayana-buddhismen er den form for buddhisme, der ligger til grund for lamaismen i Tibet og Mongoliet.

Netop denne tekst nyder stor anseelse blandt buddhisterne i Nepal, Tibet og Mongoliet.

De første udgaver af krønike-litteraturen var i faksimile. Det var egentlig tanken, at Kaare Grønbech selv skulle forestå udgivelsen af de historiske tekster. Han nåede imidlertid kun at lave nogle forarbejder til udgivelsen af det første bind inden sin død i 1957. Det blev hans nære medarbejder Walther Heissig (Bonn), der realiserede udgivelsen af dette bind. Det blev senere til flere udgivelser af krønike-litteratur fra Heissigs hånd. Altan kürdün minggan gegesütü bicig ('bogen om det gyldne hjul med de tusinde eger' MONG 517) er titlen på den første mongolske krønike, som blev udgivet af Heissig i serien Monumenta Linguarum Asia Maioris, Series Nova bd. 1 (1959). Håndskriftet af denne tekst blev fotograferet af Grønbech i 1938. Det tilhørte en mongol ved navn Sayin bayar. Han var bibliofil. Så det er intet under, at det var umuligt for Grønbech at erhverve det originale håndskrift. Samtidig har mongolen sikkert vidst, at der var tale om et yderst sjældent håndskrift. Værket er skrevet i 1739. Det er omtalt i en anden krønike, men ingen havde set originalen. Grønbech berettede om denne tekst på et møde i Videnskabernes Selskab 17. oktober 1952 ('En forsvunden mongolsk krønike').

Samlingen indeholder endvidere nogle biografier over religiøse rangspersoner. Den højeste lamaistiske rangsperson i Khalkha-Mongoliet bar titlen: Jebtsundamba Khutukhtu. Der har ialt været otte inkarnationer af dem. De havde sæde i Urga. Den første i rækken blev født 1635 og den sidste, den 


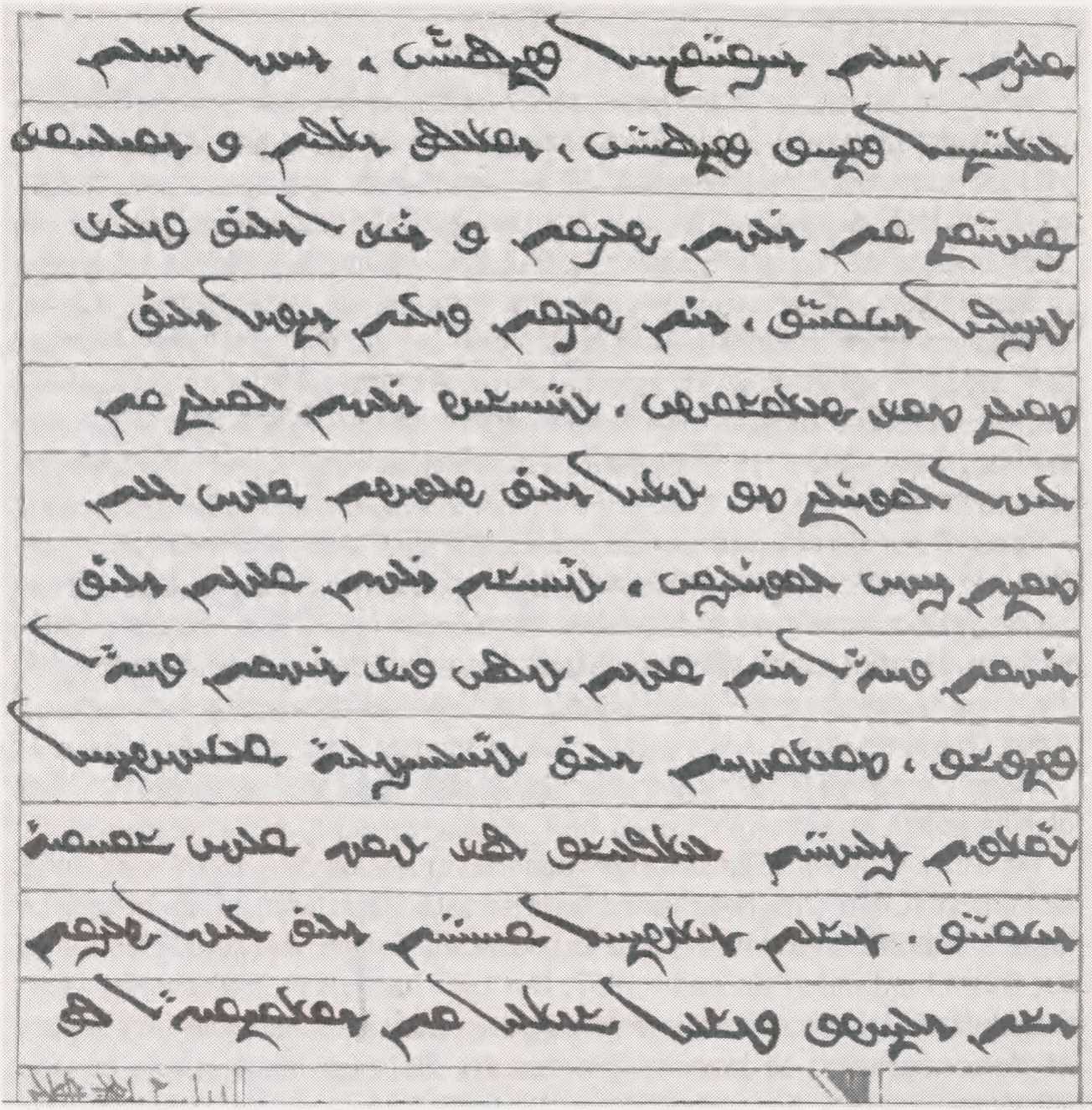

Første side af den samling mundtligt overleverede eventyr og fortællinger, som blev nedskrevet på Kaare Grønbechs foranledning i Tsakhar 1938-39. (MONG 406)

ottende Jebtsundamba Khutukhtu, døde i 1924. Han havde været statsoverhoved for Mongoliet siden 1911, da landet blev uafhængigt af Kina.

MONG 519 er en biografi over de syv første Jebtsundamba Khutukhtu'er. Teksten er udgivet af Charles Bawden (London) 1961 under titlen The Jebtsundamba Khutukhtus of Urga (Text, Translation and Notes). Tekstudgaven er baseret på MONG 519. Til det kritiske noteapparat er benyttet MONG 412, MONG 414 og MONG 558 samt fire håndskrifter fra andre samlinger.

Fra europæiske biblioteker har Heissig samlet og udgivet en række mindre tekster (77 ialt) til belysning af mongolsk folkereligion Mongolische Volksreligiöse und Folkloristische Texte (1966). Fra Orientalsk Afdelings mongol- 
ske samling har han udvalgt 39 tekster. Disse håndskrifter indeholder ritualtekster med tilknytning til bestemte fester. Endvidere indeholder de bønner og anråbelser til visse guddomme og store helte.

Mongolerne forestiller sig, at den store helt, Geser khan, bor på himlens skybjerge. I en tekst med titlen: 'anråbelse og røgelsesoffer til Geser' er der en bøn til ham om sejr i kamp, udplyndring af fjenden, rigt bytte og held med eget kvæg.

Under ildfesten, der afholdes ved vintertid, bringes ofringer til ildguden, og guddommen anråbes om et langt liv, om rigdom på kvæg og føde, om magt og styrke. I ildfesten kan man skimte noget af mongolernes førbuddhistiske, primitive religion. Denne fest har ikke vundet indpas i lamaismen. Det er til den hedenske ildgud, at bønnerne rettes. Det er til denne guddom, at offeret bringes.

Blandt disse tekster er de håndbøger, der bruges i forbindelse med bryllupsceremonierne. I disse håndbøger er der opremsninger af alle gøremål og ritualer med tilknytning til et bryllup. Andre tekster helliger sig et enkelt bryllupsritual.

Under opholdet i det sydlige Mongoli indsamlede Kaare Grønbech en række mundtligt overleverede eventyr og fortællinger. Han kom i kontakt med en ung begavet mongol, som han overtalte til at foredrage disse eventyr og fortællinger. Mongolens ældre broder skrev dem samtidigt ned. De er indgået i den mongolske samling som MONG 406, MONG 407 og MONG 408.

Der findes ingen samlet udgave af disse eventyr og fortællinger. Enkelte af dem er udgivet i forskellige publikationer. Et af eventyrene anvendes som $\emptyset$ velsesstykke i An Introduction to Classical (Literary) Mongolian (1955) af Kaare Grønbech og John Krueger.

Heissig har udarbejdet en nyttig indholdsanalyse af 12 af disse eventyr Tsakhar-Märchen (1985). Denne bog letter i høj grad arbejdet med eventyrsamlingen. Som tillæg til bogen har Heissig udgivet to eventyr, et i faksimile og et $\mathrm{i}$ translitteration.

Den ovenfor omtalte legende om den fromme Molon toyin (MONG 417) er oversat af Heissig i Helden-, Höllenfahrts- und Schelmengeschichten der Mongolen (1962).

Walther Heissig har altid gjort flittig brug af den mongolske samling. Hans interesseområde er bredt: litteratur, historie, religion og kulturhistorie i almindelighed. De mange henvisninger til samlingen i hans talrige artikler og bøger vidner om, at han ofte har rettet sin opmærksomhed mod de mongolske tekster i Orientalsk Afdeling. Dette gælder for eksempel værker som Ein Volk sucht seine Geschichte (1964), Mongolische Literatur i Handbuch der Orientalistik (1964), Geschichte der mongolischen Literatur 1-2 (1972), Die 
Religionen der Mongolei i Die Religionen der Menschheit bd. 20 (1970).

En anden kendt mongolist, Charles Bawden, har især interesseret sig for de folkereligiøse tekster. Han har benyttet to håndbøger (MONG $260 \mathrm{og}$ MONG 125) i skapulamanti, dvs. forudsigelse ved hjælp af skulderblade, i en artikel om dette emne i Central Asiatic Journal (1958-1959).

Tekstgruppen: divination og astrologi omfatter 45 håndskrifter. Dem har Bawden gjort brug af i artiklen "Astrologie und Divination bei den Mongolen" (Zeitschrift der Deutschen Morgenländischen Gesellschaft, bd. 108, 1958).

Sammen med håndskrifter fra andre samlinger har Michael Weiers (Hamburg) benyttet MONG 480, kommentaren til en mahayana-buddhistisk tekst (Bodhicaryavatara) til sproglige undersøgelser (Untersuchungen zu einer historischen Grammatik des präklassischen Schriftmongolisch, 1969).

Det er naturligt, at et rytterfolk som det mongolske har nedskrevet sine erfaringer med hensyn til hestens pleje og pasning. I samlingen findes et par veterinær-tekster: MONG 62 ('metoder til sygdoms-behandling hos heste og kameler') og MONG 90 ('regler for forbedring af hestes og kamelers tilstand ved at $t \varnothing j$ re dem').

Ruth Meserve (Bloomington, USA) forsvarede i 1987 sin disputats Historical Perspective on Mongol Horse Training, Care and Management (Selected Texts). Hun har dels gjort brug af de nævnte veterinær-teksters indhold og dels reproduceret dem i disputatsen.

Det sidste nummer i katalogen (MONG 568) er et stykke indpakningspapir fra et mongolsk trykkeri i Peking. Papiret er forsynet med en xylograferet reklametekst i tre kolonner: til venstre på tibetansk, i midten på mongolsk og til højre den mongolske tekst i tibetansk skrift. Annoncen fortæller om trykkeriets formåen. Det understreges, at skriften er klar, papiret godt og prisen rimelig.

Umiddelbart skulle man tro, at dette stykke indpakningspapir med påtryk er indlemmet i samlingen som et kuriosum. Det er ingenlunde tilfældet. Kaare Grønbech kunne finde anvendelse for denne reklametekst i en artikel om mongolsk i tibetansk skrift "Mongolian in Tibetan Script" (Studia Orientalia, 1953).

Hidtil er det tekstindholdet i den mongolske samling, der er blevet behandlet. Materiale fra samlingen benyttes endvidere til illustrationer i bøger og artikler, samt til udstillinger.

I Heissigs udgivelse af folkereligiøse tekster er 12 af bogens 32 illustrationer hentet fra forskellige rituelle tekster i den mongolske samling i Orientalsk Afdeling.

I Bawdens artikel om skapulamanti er der gengivet 12 tavler med tegninger af skulderblade med revner og tydninger. De stammer fra MONG $125 \mathrm{og}$ MONG 260. 


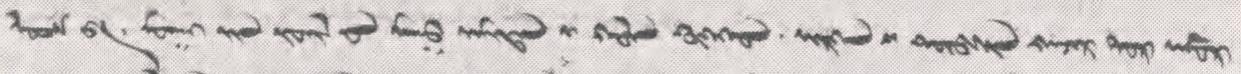

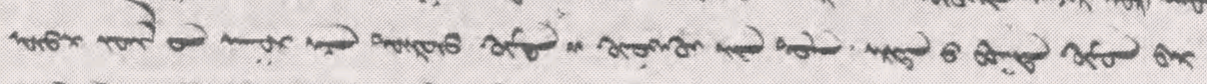

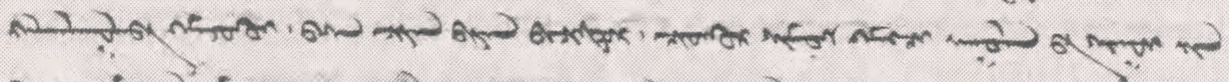

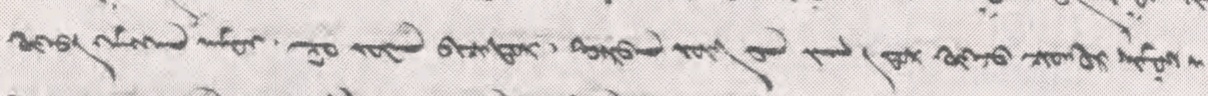

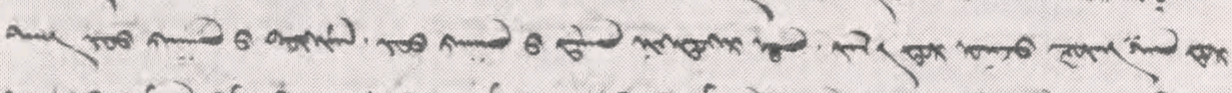

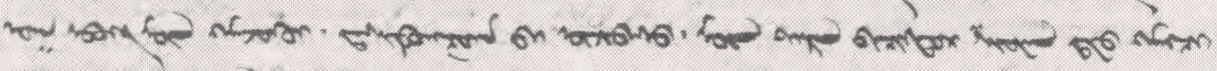

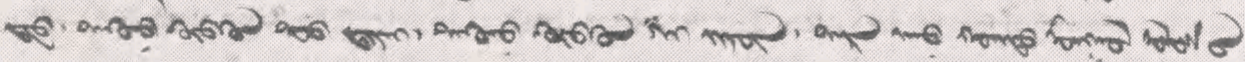

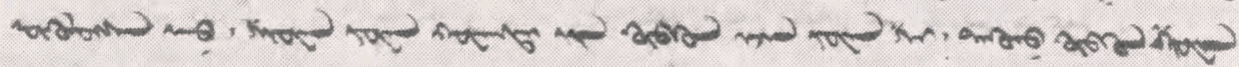

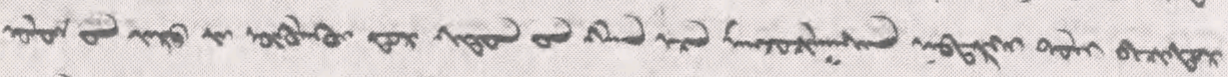

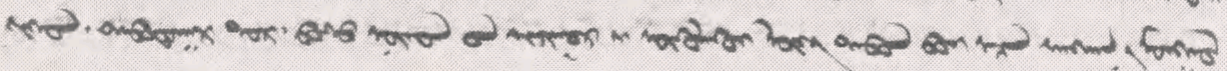

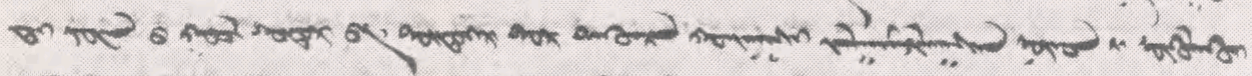

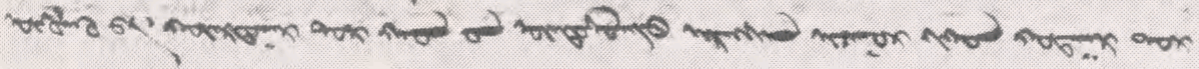

ane

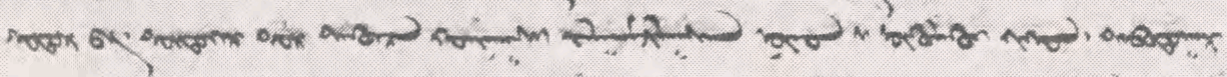

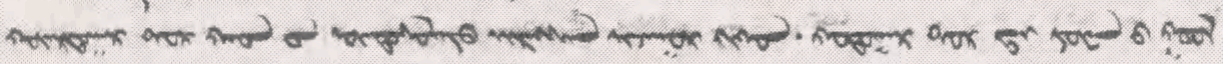

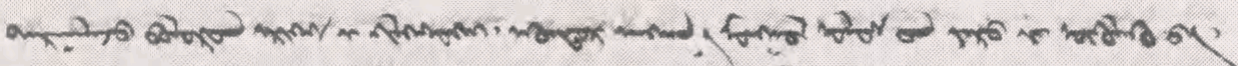

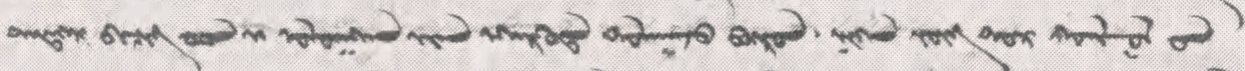

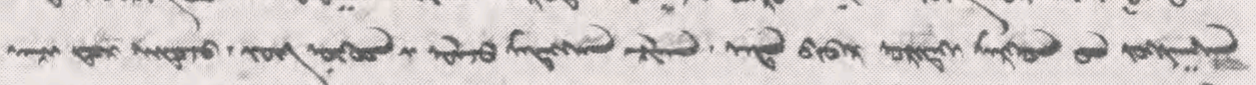

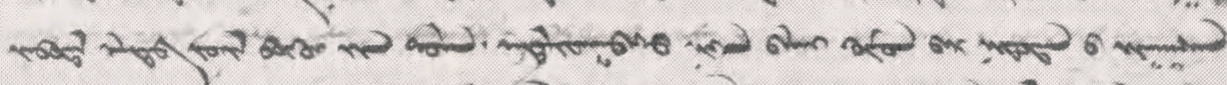

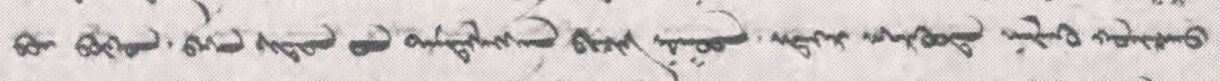

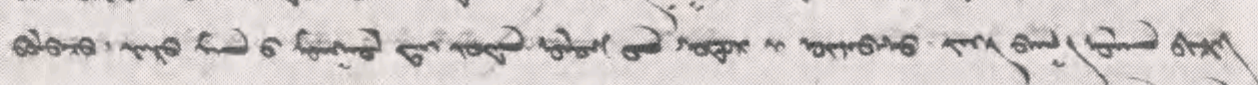

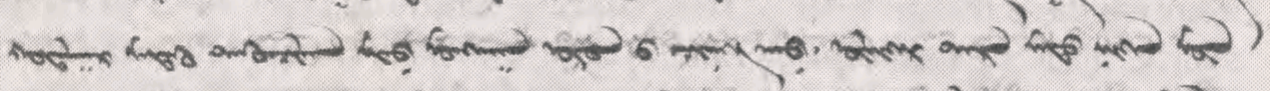

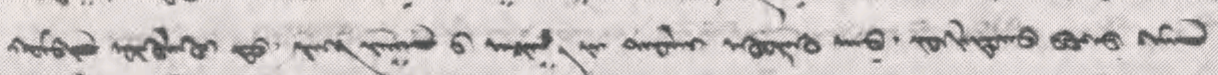

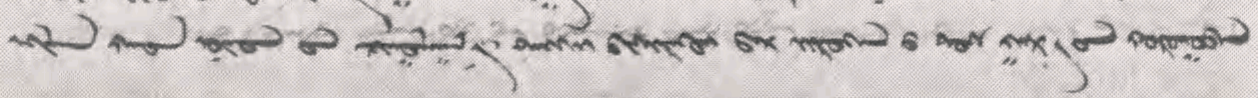

Den mongolske krønike Bolur erike fra 1774-78. Håndskriftet er fra slutningen af 1800-tallet, afskrevet $\mathrm{i}$ en dekorativ kalligrafi. (MONG 421). 
Farvebilleder fra MONG 417 (legenden om den fromme Molon toyin) er yndede illustrationsobjekter. Heissig anvender ofte flere illustrationer fra dette håndskrift i sine publikationer, for eksempel i Ein Volk sucht seine Geschichte, i oversættelsen af MONG 417 og i sin tobinds litteraturhistorie, der ellers er yderst sparsomt illustreret. I et katalog, udgivet af Haus der Kunst i München (1989) er 7 illustrationer fra dette håndskrift gengivet.

De 42 illustrationer i MONG 417 viser ikke udelukkende gruopvækkende scener fra de varme og kolde buddhistiske helveder. Mange illustrationer gengiver scener fra dagligdagen hos en velstående mongol-familie fra 1800tallet. Gennem disse billeder får vi et indblik i datidens bolig, møbler, offerborde, spiseredskaber, klæder og lignende.

Håndskrifter og bloktryk fra den mongolske samling har været udstillet såvel i Danmark som i udlandet. En stor og vidtspændende udstilling Die Mongolen - Kunst und Kultur eines alten Reitervolkes fandt sted i Haus der Kunst i München marts-maj 1989.

Orientalsk Afdeling udlånte tre håndskrifter til denne udstilling. Udstillingen blev gentaget i Hildesheim (Roemer- und Pelizaeus-Museum) julinovember 1989.

\section{Afslutning}

Som nævnt nyder vor mongolske samling stor anerkendelse blandt orientalister verden over.

Det tydeligste bevis på samlingens internationale betydning er besøget af de to mongoler fra Indre Mongoli maj 1988. Under deres gennemgang af samlingen fandt de det påkrævet at få mikrofilmet næsten 36.000 sider herfra til supplering af deres egne samlinger hjemme i Indre Mongoli. Det betød, at de måtte betale for ca. 18.000 mikrofilmoptagelser. Det er virkelig et særsyn, at man fra kinesisk side anvender et så stort beløb i fremmed valuta til et sådant formål.

Det var naturligvis et stort arbejde for Orientalsk Adelings personale at klargøre disse mange sider til fotografering. Skulle opgaven løses på en forsvarlig måde og inden for en rimelig tid, var et nært samarbejde med bibliotekets Fotografiske Atelier nødvendigt. På en enestående måde fik Atelier'et indpasset denne store ordre i dets daglige arbejdsprogram, således at optagelserne løbende kunne afvikles, og med stor dygtighed og omhu affotograferede Atelier'ets personale dette ofte vanskeligt reproducerbare materiale. 


\section{LITTERATUR}

TEKSTUDGAVER OG OVERSÆTTELSER:

ALTAN GEREL: Die westmongolische Fassung des Goldglanzsutra, hrsg. von

Erich Haenisch, Leipzig 1929. (MONG 557).

BAWDEN, CHARLES:The Jebtsundamba Khutukhtus of Urga.Text, Translation and Notes. (Asiatische Forschungen 9). Wiesbaden 1961.

GRøNBECH, KAARE and JOHN R. KRUEGER: An Introduction to Classical (Literary) Mongolian. Wiesbaden 1955.

HEISSIG, WALTHER:Helden-, Höllenfahrts- und Schelmengeschichten der Mongolen. Aus dem Mongolischen übers. von Walther Heissig. Zürich 1962. (MONG 417).

Die Familien- und Kirchengeschichtsschreibung der Mongolen. (Asiatische Forschungen 16). Wiesbaden 1965. (MONG 143).

Mongolische Volksreligiöse und Folkloristische Texte aus Europäischen Bibliotheken mit einer Einleitung und Glossar, hrsg. von Walther Heissig. Wiesbaden 1966.

- Zur Überlieferung der Üge-Dichtung, 1. Vier unbekannte Üge. (Zentralasiatische Studien 1, 163 - 235). Wiesbaden 1967. (MONG 352 og MONG 486).

Tsahkar-Märchen. Nach Aufzeichnungen aus dem Jahre 1938-39 beschrieben und eingeleitet von Walther Heissig. (Asiatische Forschungen 87). Wiesbaden 1985. (MONG 406 og MONG 408).

ISIBALDAN: Erdeni-yin erike (1835). Mongolische Chronik der Lamaistischen Klosterbauten der Mongolei, hrsg. von Walther Heissig. (Monumenta Linguarum Asiæ Maioris, Series Nova 2). København 1961. (MONG 420).

JIMBADORJI: Bolur toli, 'Spiegel aus Bergkristall' (1834-1837), hrsg. von Walther Heissig. (Monumenta Linguarum Asiæ Maioris, Series Nova 3). København 1962. (MONG 350).

POPPE, NICHOLAS: The Diamond Sutra. Three Mongolian versions of the Vajracchedika Prajnaparamita. Texts, translations, notes, and glossaries. (Asiatische Forschungen 35, 11-97). Wiesbaden 1971. (MONG 62, MONG 331 og MONG 472).

SIREGETUU GUOSI DHARMA: Altan kürdün minggan gegesütü bicig (1739). Eine mongolische Chronik, hrsg. von Walther Heissig. (Monumenta Linguarum Asiæ Maioris, Seria Nova 1). København 1958. (MONG 517).

SUBUD ERIKE: ('Ein Rosenkranz aus Perlen'). Die Biographie des 1. Pekinger lCan skya Khutukhtu, hrsg., übers. und komm. von Klaus Sargaster. (Asiatische Forschungen 20). Wiesbaden 1967. (MONG 386).

\section{ALMENE VÆRKER OG ARTIKLER:}

BARR, KAJ: Kaare Grønbech (Det kongelige danske Videnskabernes Selskab, Overs. dan. Vid. Selsk. 1957-58 (1958), 80-98). København 1958.

BAWDEN, C.R.: The Supernatural Element in Sickness and Death according to Mongol Tradition. (Asia Major 8, 215-257). London 1950-51. 
- Astrologie und Divination bei den Mongolen - die schriftlichen Quellen. (Zeitschrift der Deutschen Morgenländischen Gesellschaft 108, 317-337). Wiesbaden 1958.

- On the Practice of Scapulimancy among the Mongols. (Central Asiatic Journal 4, 1-31 + 12 plates). The Hague-Wiesbaden 1959.

- Calling the Soul: a Mongolian Litany. (Bulletin of the School of Oriental and African Studies 25, 81-103). London 1962.

- Einiges zu den Ethnographika der Chalcha und Burjaten im Museum für Völkerkunde zu Leipzig. (Jahrbuch des Museums für Völkerkunde zu Leipzig 25, 79-91). Berlin 1968.

EDELBERG, LENNART: Arselan. Et udblik over dansk forskning i Centralasien. (Naturens Verden 1958, 257-289). København 1958.

GRøNBECH, KAARE: Sprog og Skrift i Mongoliet. (Geografisk Tidsskrift 43, 56 93). København 1940.

- $\quad$ En forsvunden mongolsk krønike. (Det kongelige danske Videnskabernes Selskab, Overs. dan. Vid. Selsk. 1952-53 (1953), 32). København 1953.

- Mongolian in Tibetan Script. (Studia Orientalia 19:6). Helsinki 1953. HEISSIG, WALTHER: Die Pekinger Lamaistischen Blockdrucke in Mongolischer Sprache. (Göttinger Asiatische Forschungen 2). Wiesbaden 1954.

- $\quad$ Ein Volk sucht seine Geschichte. Düsseldorf-Wien 1964.

- Mongolische Literatur. (Handbuch der Orientalistik 1. Abt., 5. Bd. (Altaistik), 2. Absnitt (Mongolistik), 227-274). Leiden-Köln 1964.

- $\quad$ Die Religionen der Mongolei. (Die Religionen der Menschheit 20, 293 428). Stuttgart 1970.

- Catalogue of Mongol Books, Manuscripts and Xylographs, by Walther Heissig assisted by Charles Bawden. (COMDC 3). Copenhagen 1971.

- Geschichte der Mongolischen Literatur. Bd. 1-2., Wiesbaden 1972. WEIERS, MICHAEL: Untersuchungen zu einer historischen Grammatik des präklassischen Schriftmongolisch. (Asiatische Forschungen 28). Wiesbaden 1969.

Artiklen Orientalsk Afdelings mongolske samling vil udkomme særskilt i serien af introduktioner til Special- og sarsamlinger i Det kongelige Bibliotek. 